\title{
THE NEW FRONTIERS OF \\ LATE ANTIQUITY IN THE NEAR EAST. FROM DIOCLETIAN TO JUSTINIAN ${ }^{*}$
}

\author{
ARIEL S. LewiN
}

The present article aims to discuss a more general issue: is it methodologically correct to argue that all late antique near-eastern frontiers stretching from the Euphrates to the Red Sea must be seen as a more or less coherent system having the same demographic, economic and military features in all its sections? In the last years, a fundamental change has occurred in the ways scholars have perceived the character of the lateantique Near East: they have stressed how it was a world where economy and commerce developed, cities were thriving, the number of settlements in the countryside was expanding, and a demographic peak was attained. The refreshing air that penetrated into the scholarly world was, at least to a large degree, the result of new archaeological campaigns carried out according to modern methodologies and using better criteria for dating ceramic material. In fact, excavations and surveys conducted at several sites showed the extraordinary vitality of late-antique settlements. ${ }^{1}$

A stimulating introduction to an important volume has thus stated confidently that (and this is worth quoting at length): "The permanent deployment of soldiers in the East acted as a stimulus for settlement in the desert fringes, especially following the reorganisation of the limotrophe from the Red Sea to the Euphrates under Diocletian. Centres ... developed in such a climate ..., when limitanei manned the impressive chain of posts and mansios on the fortified Strata Diocletiana, the military road built to quickly move troops along the frontier and which

* Geoffrey Greatrex must be thanked for his support in the revision of the present article. Moreover, Denis Genequand, Markus Gschwind, Michaela Konrad and Minna Lönnqvist offered useful information. Conor Whately and Geoffrey Greatrex were kind enough to supply me with some work before publication.

${ }^{1}$ For an overview see A. Walmsley, 'Byzantine Palestine and Arabia: urban prosperity in Late Antiquity', in N. Christie-S.T. Loseby (eds.), Towns in Transition. Urban Evolution in Late Antiquity and the Early Middle Ages (Aldershot 1996), 126-158; B. Ward-Perkins, 'Specialised production and exchange', in A. Cameron-B. Ward-Perkins-M. Whitby (eds.), $C A H 14$ (Cambridge 2001²), 346-391. 
stretched from Bostra to the Euphrates ... In this period of demographic growth and cultural and military reorientation, which saw the Church ubiquitous even in the desert margins and the army entrench itself in the Syrian steppe ..., the unprecedented urbanisation of central Syria hardly seems accidental. Way stations on the Strata Diocletiana policed the highway and provided security, and their garrisons attracted merchants and eventually a permanent population, as had their early imperial predecessors elsewhere".' Such observations present a stimulus for a more subtle and deeper investigation. In the sixth workshop of the present series, The Impact of the Roman Army, I already tried to show that the great economic and demographic development in the late fifth and sixth century of two different marginal areas, the Negev and Central Jordan, was not due to the presence of the army there. Other factors were sufficiently influential to cause the expansion of the settled area and to improve the economy. Moreover, it can be observed that the features of these two areas did not remain the same throughout the centuries of Late Antiquity. They both underwent changes in their economy and in developments of trade and agriculture. ${ }^{3}$

Equally, it is interesting to note that other studies have strongly argued against the idea of one generalised development for all areas of the Near East in Late Antiquity. Some areas were less vital in late antiquity than in previous times, whereas for others changes or fluctuations are less easily detectable. ${ }^{4}$ In evaluating the wide world of the near-eastern frontier, it will appear immediately clear that we are dealing here, too, with a large mosaic, in which each part had peculiar features of its own. But we can go further than this. The character of the various sections of the frontier changed several times during Late Antiquity: these changes were caused by several factors, such as the policy of the

${ }^{2}$ S. Kingsley-M. Decker, 'New Rome, new theories on inter-regional exchange. An introduction to the East Mediterranean economy in Late Antiquity', in S. KingsleyM. Decker (eds.), Economy and Exchange in East Mediterranean during Late Antiquity (Oxford 2001), 8-9.

3 A.S. Lewin, 'The Late Roman army in Palaestina and Arabia', in L. de Blois-E. Lo Cascio (eds.), The Impact of the Roman Army, (200 BC-AD 476) (Leiden-Boston 2007), 463-480.

${ }^{4}$ Ch. Ben David, 'Late Antique Gaulanitis settlement patterns of Christian and Jews in rural landscape', in A.S. Lewin-P. Pellegrini (eds.), Settlements and Demography in the Near East in Late Antiquity (Pisa-Roma 2006), 35-50; Z.T. Fiema, 'City and countryside in Byzantine Palestine. Prosperity in question', in Lewin-Pellegrini 2006, op. cit. supra, 67-88; U. Leibner, 'Settlement and demography in Late Roman and Byzantine eastern Galilee', in Lewin-Pellegrini 2006, op. cit. supra, 105-130. 
imperial government, activities of the Arab tribes, and the different pace of the development of agriculture and commerce. Moreover, as we will see, the development within such areas was subject to fluctuations, that were sometimes, but not always, connected with the presence of the army.

One main point must be stressed in order to understand the history of the late-antique frontier. The renovation of the whole near-eastern military system, as accomplished by Diocletian after the crisis of the third century, had an extraordinarily deep impact. This emperor built a series of structures and routes with the aim of reasserting the strength of the Roman Empire. His soldiers occupied marginal areas bordering on the desert, and in a couple of sections of the frontier the army was deployed beyond the sites that had been previously occupied by Septimius Severus' soldiers. No scholar can any longer maintain doubts about the existence of a grand scheme that was conceived and, at least to a large degree, accomplished by Diocletian. ${ }^{5}$ Moreover, we must observe that in the following decades his successors added some new forts along the frontier. ${ }^{6}$

My first example is the section of the frontier running from Sura to Palmyra, stretching for a length of something less than $200 \mathrm{~km}$. The Notitia Dignitatum lists three legions deployed along it, the XVI Flavia

${ }^{5}$ A.S. Lewin, 'Diocletian: politics and limites in the Near East', in Ph. Freeman et al. (eds.), Limes XVIII. Proceedings of the XVIIIth International Congress of Roman Studies (Oxford 2002), 91-101; A.S. Lewin, 'Did the Roman Empire have a military strategy and were the Jafnids a part of it?', in D. Genequand-Ch. Robin (eds.), Regards croisés de l'histoire et de l'archéologie sur la dynastie Jafnide, forthcoming. The idea that a great plan of reconstruction of the near eastern frontier was launched by Diocletian finds new support by the discovery of an inscription at Udruh revealing that the fort for the legio VI Ferrata was built around 303. See D. Kennedy-H. Falahat, 'Castra legionis VI Ferratae: a building inscription for the legionary fortress at Udruh near Petra', Journal of Roman Archaeology 21 (2008), 150-169. Moreover a new inscription reveals that the castra nova at Teima in Syria were built in 296. See M. Sartre, 'Larmée romaine et la défense de la Syrie du sud', in A.S. Lewin-P. Pellegrini (eds.), The Late Roman Army in the Near East. From Diocletian to the Arab Conquest (Oxford 2007), 263-264.

${ }^{6}$ On Qusair-as Saila (Tetrapyrgium), located between Sura and Oriza and built after 320 see M. Konrad, 'Research on the Roman and Early Byzantine frontier in north Syria', JRA 12 (1999), 400-404; M. Konrad, Der spätrömische Limes in Syrie: archäologische Untersuchungen an den Grenzkastellen von Sura, Tetrapyrgium, Cholle und in Resafa (Mainz 2001). Some forts were built in the area of the Jebel Druze around mid-fourth century. See M. Sartre, Trois études sur l'Arabie romaine et byzantine (Bruxelles 1982), 102-103; M. Sartre, 'Un nouveau dux d'Arabie', in Mélanges en l'honneur de J.P. ReyCoquais. Mélanges de l'Universitè Saint Joseph 60 (2007), 313-318. 
Firma at Sura, the IV Scythica at Oriza, and the I Illyricorum at Palmyra. This last one was stationed into its base by Diocletian and probably it was under the same emperor that the other two were established in the forts mentioned in the Notitia. ${ }^{7}$

The two most important sites located between the cities of Sura and Palmyra were Oriza and Resafa. Oriza lies approximately half way between Sura and Palmyra. This site is described in the anonymous Vita of the monk Alexander who visited it in the first decades of the fifth century as a village having rich inhabitants who harvested their fields and owned livestock. ${ }^{8}$ Resafa is listed in the Notitia Dignitatum as the base of a unit of equites promoti indigenae. Scholars are convinced that such units were deployed in their forts in the near eastern ducates in Tetrarchic time. ${ }^{9}$

According to tradition, the famous saint Sergius was martyred at Resafa during the Tetrarchic persecutions. After the christianization of the Empire, the site acquired great fame and was visited by pilgrims coming also from distant places in order to worship Sergius. The settlement expanded, eventually to attain the status of city at the time of Anastasius. Procopius affirms that Justinian built several civic buildings there and a new city wall. Moreover, he says that the same emperor established a

${ }^{7}$ Notitia Dignitatum or. $33.28 ; 33.23 ; 32.20$.

8 V. Alex. Acoem. 34; P.L. Gatier, 'Un moine sur la frontière, Alexandre l'Acémète en Syrie', in A. Rousselle (ed.), Frontières terrestres, frontières célestes dans l'antiquité (Perpignan 1995), 453-454; F. Millar, 'Community, religion and language in the MiddleEuphrates zone in Late Antiquity', SCI 27 (2008), 70-71, argues that most probably the site described in the Vita is Resafa and not Oriza. He arrives at this conclusion noting that the Vita mentions the presence of a bishop there, while it is known that at the beginning of the fifth-century Oriza, unlike Resafa, was not a bishopric. Oriza is attested as a suffragan bishopric of Resafa only at the time of Anastasius. See A.H.M. Jones, Cities of the Eastern Roman provinces (Oxford 1937), 459. However, it must be stressed that in the V. Alex. Acoem. 34 it is said that bishops (at plural) were approached by the inhabitants of the castrum on their behalf. The text does not state explicitly that the site had a bishop and that the inhabitants were asking for the support of the bishop of the castrum. P.L. Gatier 1995, op. cit. supra observes that the Vita tells how Alexander and the monks had spent three days in the desert before reaching Palmyra. This fits with the distance between Palmyra and Oriza.

${ }^{9}$ Notitia Dignitatum or. 33.27. For a discussion of the documentary evidence supporting the idea that the units of equites promoti indigenae were deployed in Diocletianic time in the near eastern bases mentioned in the Notitia see P. Brennan, 'Divide and fall. The separation of legionary cavalry and the fragmentation of the Roman Empire', in T. Hillard (ed.), Ancient History in a Modern University 2 (Grand Rapids 1998), 238244; A. Lewin, 'Limitanei and comitatenses in the Near East from Diocletian to Valens', in Y. Le Bohec-C. Wolff (eds.), Larmée romain de Dioclétien à Valentinièn Ier (Lyon 2004), 299-304. 
garrison of soldiers in the city in order to protect it from enemy assaults. The magnificent city wall with its fifteen towers and four main gates is still visibile today. Among the collapsed structures of Rusafa, archaeologists have detected the presence of some large churches. The evidence proves that the site was a thriving one, adorned with colonnaded streets, courtyards and civil buildings. The quality of the decoration of the monuments, in particular of the north gate, reveals the prosperity the city had attained in the sixth century. ${ }^{10}$

Palmyra, after having been seriously damaged at the time of its revolts during Aurelian's reign, received a legionary garrison in the reign of Diocletian, which was stationed in the castra built in the area of the temple of Bel. The extraordinary wealth of the city had gone by that time, but the site still maintained its city status, although populated by far fewer inhabitants than in the past. Under Diocletian new baths were built and in 328 a curator civitatis restored the columns of a portico. Palmyra is still attested as being a polis in the fifth and sixth century. ${ }^{11}$

Procopius affirms that Justinian found the site almost completely deserted. He strengthened its defences, provided it with abundant water and a garrison of troops. ${ }^{12}$ According to Malalas, in 527 Justinian decided to increase Palmyra's military importance, by adding a unit, perhaps a comitatensian one, to the limitanean garrison already present in the city. Moreover, the seat of the dux Phoenicis Libanensis was shifted from Emesa to Palmyra. At the same time the emperor invested large sums of money in order to embellish Palmyra with churches and public buildings. ${ }^{13}$ Finally, it is interesting to observe that the presence of some late antique farmsteads in the hinterland of the city has been detected. It

${ }^{10}$ Notitia Dignitatum or. 33.27; M. Konrad, 'Flavische und spätantike Bebauung unter der Basilika B von Resafa', DaM 6 (1992), 313-402; E. Key Fowden, The Barbarian Plain. St. Sergius between Rome and Iran (Berkeley 1999); G. Brands, Die Bauormanentik von Resafa-Sergiupolis (Mainz 2002).

${ }^{11}$ See M. Baranski, 'The Roman army in Palmyra. A case of adaptation of a pre-existing city', in E. Dabrowa (ed.), The Roman and Byzantine Army in the East (Krakow 1994), 9-17. For a collection of the relevant sources see S.P. Kowalski, 'Late Roman Palmyra in literature and epigraphy', Studia Palmyrenskie 10 (1997), 39-62. For the military camp built by Diocletian at Palmyra see M. Gawlikowski, Palmyre VIII. Les principia de Dioclétien. "Temples des Enseignes" (Warszawa 1984); S.P. Kowalski, 'The camp of the legio I Illyricorum in Palmyra', Novensia 10 (1998), 189-209.

12 Procopius, De aedificiis 2.11.10-12.

13 Malalas 426; G. Greatrex, Rome and Persia at War, 502-532 (Leeds 1998), 151; G. Greatrex, 'Dukes of the Eastern frontier', in J. Drinkwater-B. Salway (eds.), Wolf Liebeschuetz Reflected (London 2007), 92. 
appears that they were inhabited during the sixth century, but only future research will show whether or not their occupation predates Justinian's time. $^{14}$

Sura was valiantly defended by the soldiers and by the civil population before suffering capture and destruction by Chosroes I and his army in 540. Procopius narrates that Justinian later provided a stout wall for the city, which had previously only been protected by quite a weak fortification. Actually, the city wall displays the presence of two different parts: the western one is made of ashlars from local stone; the eastern part has a rubble stone base and mud bricks. The two sections are divided by another wall, which runs directly to the western curtain wall of the fort. It is known from Procopius that the fortifications erected by Diocletian were made of mud bricks. Consequently, we must suppose that the new vicus built by Justinian was the one comprised by the western circuit. Equally, a fort is still visible at the site. It is located on a corner of the older settlement and has its western wall running directly into the eastern one of the new settlement. Its features indicate that it is the fort built by Justinian, most probably on the ruins of the older one that had had the same groundplan. ${ }^{15}$

Some minor military installations had been built along this section of the frontier, such as Tetrapyrgium, Cholle and Juwal between Sura and Oriza; Sukneh between Oriza and Palmyra. Archaeological research reveals that vici arose around the forts and that agriculture was practised. ${ }^{16}$ Detailed campaigns of excavations conducted at Tetrapyrgium have shown that the fort was built some time after 320 , as an addition to the project of renovation of the frontier launched by Diocletian. The archaeological evidence points to a continuous occupation of the fort until around 580. The vicus underwent its most intense development phase in the fifth and sixth century and was inhabited until Ummayad

${ }^{14}$ D. Genequand, 'Projet "implantations umayyades de Syrie et de Jordanie”. Rapport de prospection (Juin/Juillet 2002)', Schweizerische-Liechtensteinische Stiftung für Archaeologische Forschungen im Ausland (2003), 31-68.

${ }^{15}$ See Procopius, De bellis 2.5.8-33; De aedificiis 2.9.1. In the twenties of the sixth century some soldiers from the Balkans had been transfered to Sura. See Malalas 442. Again, that would not imply that they found the city void of a military presence. For an important interpretation of the ruins of the site see M. Konrad, 'Research on the Roman and Early Byzantine frontier in north Syria', JRA 12 (1999), 398-400; Konrad 2001, op. cit. (n. 6), 5-12.

${ }^{16}$ Konrad 1999, op. cit. (n. 15), 392-410; Konrad 2001, op. cit. (n. 6); G. MajcherekA. Taha, 'Roman and Byzantine layers at Umm el-Tlel: ceramics and other finds', Syria 81 (2004), 229-248. 
times. Most probably, the same happened also at the other sites along the route between Palmyra and Sura. ${ }^{17}$

Unlike Tetrapyrgium, whose fort was built on the corner of the vicus, Cholle has a quadriburgium built in the middle of its vicus. The vicus itself was protected by a wall. The layout of the settlement is a hippodamian one, regularly aligned with respect to its circuit wall. Such a fact, combined with the observation that the walls of the vici of Tetrapyrgium and Cholle reveal quite similar features, suggests the existence of a wellconceived plan behind the renovation of both settlements. According to the archaeological investigations, the city wall at Tetrapyrgium was built in the sixth century. However, some considerations may indicate the existence of an older city wall, running on the same lines of the new one.

It has been argued that Tetrapyrgium and Cholle were built in the context of a general program, most probably supported by the army. If so, the purpose behind it could have been to facilitate the logistics along the network of a militarized route system. Moreover, the vici were used as stopping-places for caravans, traders and nomads. ${ }^{18}$ Resafa apart, all the military sites were built in natural spring-fed oases. ${ }^{19}$ We may easily infer that the geographical features of this section of the frontier made easier the conditions of life for the soldiers and for a civilian population. The sites were capable of developing agriculture and became magnets for commercial activity.

Two fascinanting literary texts describe the character of life along this stretch of frontier. The first of them is the the Anonymous Passio of the Saints Sergius and Bacchus. The setting of the events is the route running along the border of the desert between Barbalissus and Sura and from there to Tetrapyrgium and Resafa. According to the text, it was at the time of the Tetrarchy that the dux of Euphratensis tried to convince Sergius to abandon the Christian faith; after Sergius's vigorous denial, the military commander compelled him to walk for several miles along the frontier route, from one fort to the other, with spikes fixed in his feet. Sergius

\footnotetext{
17 See the detailed discussion of the material finds by Konrad 2001, op. cit. (n. 6), 9910o. See also M. Konrad, 'Roman military fortifications along the eastern desert frontier: settlement continuities and change in North Syria, 4th-8th century AD', in K. Bartl-A alRazzaq Moaz (eds.), Residences, Castles, Settlements, Transformation Processes from Late Antiquity to Early Islam in Bilad al-Sham (Rahden 2008), 433-453.

${ }_{18}$ Konrad 2001, op. cit. (n. 6), 98-113.

19 Key Fowden 1999, op. cit. (n. 10), 71-73.
} 
displayed an extraordinary endurance but was eventually beheaded in the castrum of Resafa. ${ }^{20}$

The second extraordinary text is the Vita of the monk Alexander the Akoimeites, written in Greek in the sixth century, but derived from an original Syriac text, most probably written by one of his companions in the second part of the fifth century. According to the Vita, at a certain stage of his activity, at the end of the first or at the beginning of the second decade of the fifth century, Alexander and his group of monks walked along a series of fortresses built every ten to twenty miles from each other for defense against the barbarians. The soldiers and their officers lived there, and Alexander used to preach to the inhabitants of the castra, soldiers, officers and, most probably, civilians as well. The world described by the Vita was a dangerous one: bandits used to attack travellers and to steal livestock; years of drought were always a powerful threat to the life of the inhabitants. ${ }^{21}$

Again, as in the case of the aforementioned Passio, we can note the existence of a series of military fortresses located along a route bordering the desert. The presence of the soldiers was dictated by the need to protect the area from Arab attacks. However, we must note that in the Vita of Alexander a caravan of Saracens leading their camels is described as providing help to the monks. The Passio reveals that Resafa was a place where different worlds and cultures had the chance to meet each other. In fact, the Saracens used to visit the martyrium of the saint and together with the inhabitants of the castrum and other pilgrims worshipped him there.

Both literary works were written in the second half of the fifth century. As we have seen, Sergius' martyrdom described in the Passio pertains to the Tetrarchic age; in his turn Alexander visited the same section of frontier in the early fifth century. The setting of both the stories is a frontier route in the steppe bordering the desert where a series of fortresses had been been built at a more or less regular distance one from the other. It is interesting to observe that according to the witness of the author of the Vita such a route with forts and other military structures located along it was called limes. ${ }^{22}$

\footnotetext{
${ }^{20}$ Key Fowden 1999, op. cit. (n. 10), 7-26.

21 V. Alex. Acoem. 33-34; Gatier 1995, op. cit. (n. 8); D. Caner, Wandering, Begging Monks. Spiritual Authority and the Promotion of Monasticism in Late Antiquity (Berkeley 2002), 249-280.

${ }^{22}$ See C. Zuckerman, 'Sur le dispositif frontalier en Arménie', Historia 47 (1998), 112118. The Passio cannot prove that all the structures of the system were already established
} 
Procopius affirms that Justinian established a garrison in Palmyra. However, as we have seen, Malalas provides a more detailed description of the same event. He reveals that when Justinian transferred a new unit, presumably a comitatensian one, to Palmyra, there were already some limitanei who were garrisoning the city. ${ }^{23}$ Consequently, it must be noted that Procopius's description is in some way deceptive. Equally, Procopius praises Justinian for having established a garrison of soldiers in Resafa, in order to defend its city wall against Saracen assaults. ${ }^{24}$ It is doubtful if this information is more reliable than that about Palmyra. Most probably, it was beyond his interest to specify that some soldiers were already present in the sites. Alternatively, scholars have argued that Procopius did not visit Palmyra or Resafa. ${ }^{25}$ If this were true, he would not have had any first-hand knowledge about that section of the frontier, and we can consequently suspect that he failed to know how some soldiers were already stationed in the city before Justinian transferred other troops there.

In 542, when Chosroes attacked Resafa, there were two hundred soldiers to defend the city. ${ }^{26}$ That was a small garrison, perhaps a weakened limitanean unit. It is possible that in previous times, immediately after Justinian had transferred some soldiers, perhaps at the same time as he increased the garrison of Palmyra, the garrison had been larger. The more relaxed atmosphere of the years after the conclusion of the treaty of Eternal peace, combined with the financial problems of the imperial administration, could have brought about a reduction of the army at the frontiers. It is true that the archaeological research conducted by Michaela Konrad has shown that Tetrapyrgium was continuously occupied until around $580 .{ }^{27}$ Nonetheless it remains possible, and indeed probable, that in peace time the units were kept under-strength. However, Konrad also argues that analysis of the pottery and coins indicates that an Arab garrison was installed at Tetrapyrgium at the time of the alliance of Arab tribes

at the time of Diocletian. In fact the fort of Tetrapyrgium, although mentioned in the narration provided by the author as one of the military installations crossed by Sergius and his persecutors, was built only later, some time after AD 320. See Konrad 2001, op. cit. (n. 6), 98-99.

${ }^{23}$ Procopius, De aedificiis 2.11.10.

${ }^{24}$ Procopius, De aedificiis 2.9.8.

25 Th. Ulbert, 'Procopius de aedificiis. Einige Überlegungen zu Buch II, Syrien', AnTard 8 (2000), 142-145, is sceptical about the idea that Procopius had a first hand knowledge of Resafa.

${ }^{26}$ Procopius, De bellis 2.20.13.

27 See Konrad 2001, op. cit. (n. 6), 100; 112-113. 
with Byzantium, under the leadership of the Ghassanids. ${ }^{28}$ If so, such a presence would give us a glimpse of the new situation which was emerging on the edge of the empire, with federates occupying some frontier forts.

As far as the embellishment of Resafa is concerned, we must note that Procopius narrates that Justinian surrounded the site with a city wall and stored up a great quantity of water there and thus provided the inhabitants with a bountiful supply. Moreover, he added houses, stoas and other buildings to the place.

Yet two inscriptions discovered in the last decades cast serious doubt on the reliability of Procopius' description. The first of them recalls that work on the building of the so-called basilica B begun in 518; the other one that, approximately in the same years, a cistern was constructed. It is significant to observe that they indicate that both the projects were financed by the episcopal see of the city. ${ }^{29}$ On the other hand, it must be noted that Procopius does not actually say that Justinian built the churches. Moreover, the first inscription recalls the time of the beginning of the works, but we cannot establish when they were finished. If so, we might assume the existence of two phases of works at Resafa: in the first the churches were built; the regular plan of the city, the circuit and the general layout were established later. ${ }^{30}$

We have already noted that, unlike the other military sites along this section of the near eastern frontier, Resafa was not an oasis. It was not supplied by wells. It was, however, located on the intersection of some wadis. Water from some wadis had to be collected and rainwater was stored in cavelike hollows in the ground and in cisterns. Elizabeth Key Fowden has observed that "Aerial photograph of Rusafa show traces of gardens with enclosures ... and built basins and barrages ... With the help of collected rainwater, the area under the walled settlement of Rusafa could conceivably have supported orchards, olive and fig trees and even grain, but no evidence survives to bear witness to such industry". ${ }^{31}$ To

28 Konrad 2001, op. cit. (n. 6), 100; 112-113.

29 See Ulbert 200o, op. cit. (n. 25), 143-145. See also Key Fowden 1999, op. cit. (n. 10), 77-92.

30 See the observations advanced by R. Harrison, CR 34 (1984), 105-106 reviewing the important study by W. Karnapp, Die Stadmauer von Resafa in Syrien (Berlin 1976). Nonetheless, it must be observed that Harrison argued that the construction of the cistern belonged to the first building phase. For the chronology of the building of the city wall see also the discussion by Konrad 2001, op. cit. (n. 6),14-15, n. 99.

31 Key Fowden 1999, op. cit. (n. 10), 72. 
conclude, it seems clear that the settlement expanded only as a result of the establishment and growth of Sergius' worship. At the beginning, it had been a fort surrounded by a vicus, as other sites along the route. Eventually it attained the status of city under Anastasius and took the name of Sergiopolis. It was under that emperor that new important building works were planned. However, it was only later, under Justinian, that the city finally had the chance of displaying a completely new urban look, protected by magnificent city walls. ${ }^{32}$

The second section of the frontier that I intend to discuss is the one leading from Palmyra to Thelsee and Damascus in the steppe south of the Jebel Rawaq. It passed through the slopes of the Jebel at an altitude of approximately 500 meters, at the edge of the hamad. Diocletian built a series of forts there along a route that the French scholars have designated "la route des khans". Some milestones found along this route reveal that it was called Strata Diocletiana. The same name was given to at least a part of the frontier line connecting Palmyra with Sura, where a similar milestone had been found at Arak, 8 miles north of Palmyra. Moreover, it must be observed that the Strata Diocletiana, far from being a simple linear route, was composed of a series of different trunks. A good example of such a situation is provided by the trunk that diverted from the main one from Palmyra to Damascus, stretching $21 \mathrm{~km}$. to the south of Palmyra to the fort at al Bakhra, identified with the ancient Avatha. ${ }^{33}$

It is possible that at the time of Septimius Severus only a couple of forts existed along "la route des khans", at places where there were access points through the chain of the Jebel Rawaq. If so, we could assume that at the time of that emperor no coherent system with a military route and a series of forts had yet been built south of the Jebel Rawaq and that the best

${ }^{32}$ Key Fowden 1999, op. cit. (n. 10), 70-72. See now T. Ulbert, '50 Jahre Forschungen in Resafa/Sergiupolis. Struktur und Kontinuität', in K. Bartl-A. al-Razzaq Moaz (eds.), Residences, Castles, Settlements (Rahden 2008), 19-30; D. Sacks, 'Resafa-Sergiupolis/Rusafat Hisham-neue Forschungsansätze', in Bartl-al-Razzaq Moaz 2008, op. cit supra, 3144 .

33 Th. Bauzou, 'Epigraphie et toponymie: le cas de la Palmyréne du Sud-Ovest', Syria 70 (1993), 27-50; D. Genequand, 'Al-Bakhra' (Avatha), from the Tetrarchic Fort to the Umayyad Castle', Levant 36 (2004), 225-242. A unit of equites promoti indigenae was stationed in the fort of Avatha in Diocletianic time. See Th. Bauzou, 'Activité de la mission archéologique "Strata Diocletiana" en 1990 à 1992', Chronique archéologique en Syrie (1992), 136-140. 
connection between Palmyra and Damascus was still the route running north of the mountain chain. ${ }^{34}$

It is fundamental to note that archaeology has shown that, contrary to what we have observed about the route between Sura and Palmyra, no vici arose near the forts along the route of the khans. Moreover, it is difficult to prove that interval towers were built between one fort and another. It is true that some minor sites have been noted between different forts, but it is impossible to prove that they were military installations; moreover, the date of these structures is not known. The same holds true for agriculture: in his famous book, Antoine Poidebard wrote that along the greatest part of the route he had noted the existence of water points and farmed lands. ${ }^{35}$ However, as with the case of the minor military installations, it is doubtful if the claim is supported by the evidence. In particular, it must be noted that Poidebard considered every ruin to belong to the Roman or late-Roman period, and did not envisage the possibility that they had been built earlier or later. It can be called to mind that some important studies have now shown that at sites elsewhere, where Poidebard noted huge agricultural systems, these should be dated to a much later date. ${ }^{36}$ Most importantly of all, recent investigations have detected that there were not many structures related to agriculture along "la route des khans"; consequently, it can be argued that only a limited amount of agriculture was practiced, and not around all the khans. ${ }^{37}$ Most of the area receives under $150 \mathrm{~mm}$. of annual rainfall and requires huge irrigation devices if one wishes to undertake a large scale agriculture. The soldiers got their water only from wells; barrages for keeping water were used in order to water the cattle. ${ }^{38}$ We must deduce that the soldiers who lived in the installations along that route endured a difficult life.

The Notitia Dignitatum shows that the forts along the Strata Diocletiana were still occupied by Roman soldiers around the year $400 \mathrm{AD}$. However, in a famous passage, Procopius describes how a short time before the outbreak of the war between Rome and Persia in 540, the chiefs

\footnotetext{
${ }^{34}$ See D. van Berchem, L’armée de Dioclétien et la réforme constantinienne (Paris 1952), 12-13.

35 A. Poidebard, La trace de Rome dans le désert de Syrie (Paris 1934), 36-40; 42-50.

36 See e.g. Genequand 2003, op. cit. (n. 14), 31-68.

37 This information was provided by D. Genequand.

${ }^{38}$ Th. Bauzou, 'Les routes romaines de Syrie', in J.M. Dentzer-W. Orthmann (eds.), Archeologie et histoire de la Syrie II (Saarbrücken 1989), 219; Th. Bauzou, 'La "Strata Diocletiana", in L. Nordiguian-J.F. Salles (eds.), Aux origines de l'archéologie aérienne. A. Poidebard (1878-1955) (Beyrouth 2000), 87-88.
} 
of the Arab allies of the two superpowers quarreled over some rights to a desolate land:

This country, which at that time was claimed by both tribes of Saracens is called Strata, and extends to the south of Palmyra; nowhere does it produce a single tree or any of the useful growth of corn-lands, for it is burned exceedingly dry by the sun, but from of old it has been devoted to the pasturage of some few flocks. Now Arethas-the ally of the Romansmaintained that the place belonged to the Romans, proving his assertion by the name which has long been applied to it by all (for Strata signifies a paved road in the Latin tongue) and he also adduced the testimonies of men of the oldest times. Alamoundaras, the ally of the Persians, however was by no means inclined to quarrel concerning the name, but he claimed that tribute had been given him from old for the pasturage there by the owners of the flocks. ${ }^{39}$

Later, a minister of Justinian advised the emperor not to offer the Persians a pretext for war for the sake of a small bit of land which was of absolutely no account, but altogether unproductive and unsuitable for crops. ${ }^{40}$ The Strata south of Palmyra must be identified with "la voie des khans". We must remain confident that the Roman troops had long since withdrawn from it. As Ben Isaac has observed: "The very fact that such a dispute could take place is an indication that there was no army presence there". ${ }^{41}$

39 Procopius, De bellis 2.1.1-8 (tr. H.B. Dewing). It must be stressed that until now the area has not been the subject of intensive survey. For the water systems of Manqura and Qattar see Y. Calvet-B. Geyer, Barrages antiques de Syrie (Lyon 1992), where only for the first site evidence for cultivation is presented. It must be observed that elsewhere hydraulic devices and huge agricultural systems previously supposed to belong to Roman time have been dated to late 6th-8th centuries. See D. Genequand, 'Some thoughts on Qasr al-Hayr al-Gharbi, its dam, its monastery and the Ghassanids', Levant 38 (2006), $63-83$ where it is shown that the Harbaqa dam was most probably constructed by the Umayyads.

40 Procopius, De bellis 2.1.9-11. See G. Greatrex-S.N.C. Lieu, The Roman Eastern Frontier and the Persian Wars. Part II AD 363-630 (London-New York 2002), 102-103.

${ }^{41}$ B. Isaac, The Limits of Empire. The Roman Army in the East (Oxford 1990), 211. He argues that the same was true of the section of the frontier between Sura and Palmyra. Nonetheless the documentation we have examined above proves a continuity of the military presence in the sites along that section of the frontier. Actually, Procopius is accurate enough in telling that the setting of the quarrel between Arethas and Al Mundhir was the area south of Palmyra. W. Liebeschuetz, 'The defences of Syria in the sixth century', in D. Haupt-H.G. Horn (eds.), Studien zu den Militärgrenzen Roms II (Köln 1977), 489490 connected such a disappearence of the Roman military presence along the strata diocletiana with a general weakening in the fifth century of the limitanean armies in the near eastern ducates. 
Let us now examine the section of the frontier running along the right side of the river Euphrates, from the city of Sura to the confluence of the Khabur. The most important site along that route was Zenobia, located approximately halfway along. According to Procopius, it was founded as a small city by the Palmyrenians, but later, after the collapse of their power, the Romans did not show any serious interest in taking care of it. ${ }^{42}$ Even now, Zenobia's urban plan and its solid circuit impress visitors. The city was built in a strategic position, dominating from a cliff, where the chain of the Jebel Bishri comes closer to the Euphrates and the valley has a width of only approximately $10 \mathrm{~km}$. It has a triangular shape, adapted to the features of the terrain.

It must be observed that Zenobia is not mentioned in the Notitia Dignitatum. Such an absence can be taken as a proof of the fact that no garrison was present there around $\mathrm{AD} 400$. Consequently, we must assume that it is extremely probable that Diocletian, and the other emperors after him, were not interested in deploying a military force in the site. That fits with Procopius' comments on Zenobias' decay, and his silence about any interest shown by Diocletian. According to the same writer, in Justinian's time the city walls of Zenobia had become a heap of ruins, and the place was destitute of inhabitants: "so it was possibile for the Persians freely, whenever they wished, to get into the middle of Roman territory before the Romans had word of the hostile inroad". But, still according to Procopius Justinian rebuilt it completely and filled it with inhabitants; moreover he introduced a garrison with its commander. In order to give greater strength to the circuit wall in the western part of the city he incorporated a high cliff into it. The emperor had a large and ambitious plan for Zenobia in order to enhance its civilian features: in fact, relying on the ability of two famous architects, he erected churches, baths and stoas. ${ }^{43}$

It has been noted that the long description provided by Procopius about the character of the Justinianic works seems to suggest that there were two different phases of renovation works, both undertaken by that emperor. Unfortunately, it is extremely difficult to establish the timing of the beginning of the renovations works. Moreover, it must be stressed that scholars suppose that no new fortifications on the frontier had been

42 Procopius, De aedificiis 2.8.9. See also Procopius, De bellis 2.5.4. Scholars used to tentatively identify the site with the Birtha-Asporakos mentioned in some Roman documents of the first half of the third century. For the story of the frontier in the second and third century $\mathrm{AD}$ see P. Edwell, Between Rome and Persia. The Middle Euphrates, Mesopotamia and Palmyra under Roman Control (London-New York 2008), 78; 81-85.

${ }^{43}$ Procopius, De aedificiis 2.8.8-25. 
built in the time between the eternal peace of $532 / 3$ and the invasion led by Kosroes in 540. ${ }^{44}$ Accordingly, Geoffrey Greatrex suggests that at the time of the Persian invasion in 531 "what Roman forts there were along the Euphrates here, such as Circesium and Zenobia, were in bad condition and poorly guarded" and that their strengthening occurred only some years after Chosroes' invasion..$^{45}$

Procopius writes that the Persians who invaded the Roman provinces in 531 passed through a territory in Euphratesia where there were no well-protected cities. He says that the Persians had never before that time launched an attack by marching along the bank of the Euphrates: "They disregarded the land outside the river Euphrates, which was for the most part unwatered and deserted by men" (Bell. I, 17, 25). The idea of leading an army through the route flanking the river was suggested by the chief of the Arab allies of the Persians, Al Mundhir. He said to the Persian king that: "in the land which lies outside the river Euphrates and in Syria which adjoins it there is neither a fortified city nor an army of any importance" (Bell. I, 17, 34). A few pages later Procopius narrates how the invasion materialized: "the Persians crossed the river Euphrates in Assyria, and, after passing over some inhabited country, they suddenly and unexpectedly threw their forces into Commagene" (Bell. I, 18, 2). Pseudo-Zacharias describes the character of the invasionroute employed by the Persians in a quite similar way: "The Persians passed through the desert land of the Romans" (Zach. IX, 4). Information provided by Malalas clarifies that the Persian army crossed the river near Circesium. If so, it must be clear that Procopius, in describing a land for the most part unwatered and deserted by men, intended the section of the frontier between Circesium and Sura on the right flank of the river. ${ }^{46}$

${ }^{44}$ See L.M. Whitby, 'Procopius and the development of defences in Upper Mesopotamia, in Ph. Freeman-D. Kennedy (eds.), The Defence of the Roman and Byzantine East (Oxford 1986), 717-735 with a discussion of the character and the chronology of the fortification works undertaken by Justinian; Greatrex 1998, op. cit. (n. 13), 196; Greatrex-Lieu 2002, op. cit. (n. 40), 99.

${ }^{45}$ Greatrex 1998, op. cit. (n. 13), 196. Contra Ulbert 2000, op. cit. (n. 25), 141, prefers to draw from Procopius, De bellis 2.5.2-3 that in 540 Circesium had already been strengthened by Justinian.

46 Malalas 461 with the observations offered by Greatrex 1998, op. cit. (n. 13), 196197 , n. 35 . On the character of the work written by the so-called Pseudo-Zacharias and on the source used by this author see now G. Greatrex, 'Le Pseudo-Zacharie de Mytilène et l'historiographie syriaque au sixième siècle', in M. Debié (ed.), L'Historiographie syriaque (Paris 2009), 33-55. For a new translation of the text see R. Phenix-C. HornG. Greatrex, The Miscellaneous History of Pseudo Zacharias of Mytilene (Liverpool 2010). 
Finally, Procopius says that the Persians on their return home after having devastated the provinces of Syria and Euphratesia stopped opposite the city of Callinicum: "From there they were about to march through a country absolutely uninhabited by man, and thus to quit the land of the Romans; for they purposed no longer to proceed as before, keeping to the bank of the river" (Bell. I, 18, 13-14).

It must be noted that when he describes the invasion of the year 540 led by Chosroes I, Procopius reveals the existence of a different scenario. Chosroes attacked the Roman Empire, coming again through the land near the Euphrates, in Euphratesia. He passed near Zenobia, which is now described by the writer as a city. However, in the following narration of the events Procopius stresses the fact that Zenobia was not an important center at that time. "Chosroes upon learning that the place was not important and observing that the land was untenanted and destitute of all good things feared lest any time spent by him would be wasted by an affair of no consequence. He attempted to force the place to surrender, but meeting no success he hastened his march forward" (Bell. II, 5, 7).

Accordingly, Procopius' passages seem to imply that in 531 Zenobia was still a deserted site; however, when the Persian army skirted it in 540 it was an inhabited city, presumibly protected by some defences. If so, it could be argued that the first rebuilding works were undertaken during the thirties and that the most important phase of the renovation of the city occurred later, at the end of the forties or at the beginning of the fifties, when Justinian decided to strengthen the city walls. In fact, one of the engineers mentioned by Procopius as involved in the rebuilding of Zenobia, Isidorus the younger, from Miletos, is attested as responsible for some important works at the city walls of Chalcis in $550 / 551 .{ }^{47}$

As we have seen, there is a serious problem with a chronology implying that a first phase of building works occurred in the thirties of the sixth century: in fact, it is possible that, as happened in previous cases,

47 See the important discussion by F. de' Maffei, 'Zenobia e Annoukas: fortificazioni di Giustiniano sul medio Eufrate. Fasi degli interventi e data', Milion 2 (1990), 135-177, in disagreement with the evaluation of the phases of the works offered by J. Lauffray, Halebiyya-Zenobia. Place forte de limes Orientale et la Haute Mésopotamie au VIe siècle, I (Paris 1983), who argues that it was Anastasius who begun to rebuild Zenobia. Actually such an idea does not appear convincing: Procopius usually admits which works were initiated by that emperor; moreover the sources record that Anastasius was active in reinforcing the defences in Osrhoene, Mesopotamia and Armenia, but are silent about his involvment in projects in Euphratesia. An exception was represented by his interest in embellishing Resafa, dictated by the fact that the site was a very important Christian shrine. 
the treaty of the so-called aeternal peace stipulated in 532/533 obliged Romans and Persians not to build new fortifications along the frontiers. ${ }^{48}$ I have discussed the topic elsewhere, trying to verify if it is possible to argue that some exceptions were made to such a scheme. ${ }^{49} \mathrm{I}$ am not sure to have arrived at sufficient conclusions there; yet at least two important points have to be advanced now.

Firstly, I feel less confident than in my previous study that Procopius' passages in the first book of the Bella suggest beyond reasonable doubt that at the time of the Persian attack the area on the right bank of the Euphrates between Circesium and Sura was deserted. As far as Zenobia is concerned, Procopius affirms that Justinian made it a solid stronghold (phylakterion) and an offensive fortress (epiteichisma) against the Persians. ${ }^{50}$ At first sight that would imply that from the beginning, Zenobia's building was conceived as a strategic reaction to the use by enemy forces of the route on the right flank of the Euphrates as a penetration axis. If so, Justinian became interested in strengthening Zenobia only after 531 or, alternatively, after the invasion of AD 540. Procopius' statement is, however, to a certain degree, misleading. The de aedificiis was a panegyrical work, aimed at magnifying Justinian's achievements, and we cannot expect from it a complete list of all the works launched by Justinian or a clear description and chronology of different stages of execution of these works. ${ }^{51}$

If this is true, it remains possible that Justinian rebuilt Zenobia before the outbreak of the first Persian war, in the same years in which he accomplished the building of the new circuit at Resafa and strengthened the military presence in Palmyra. Procopius stresses that the Saracen threat pushed the emperor to reinforce the defences and the military presence there. We may surmise that the same kind of considerations led Justinian to plan the foundation of a well-fortified new city in the Middle Euphrates area, in order to stress the weight of the Roman presence in that area. At a later stage the route on the right flank of the river became a focus

\footnotetext{
${ }^{48}$ See above Whitby 1986, op.cit. (n. 44), and Greatrex 1998, op. cit. (n. 13).

49 See the discussion in A.S. Lewin, Popoli terre e frontiere dell'impero romano. Il vicino oriente nella tarda antichità I: il problema militare (Catania 2008), 123-140.

${ }^{50}$ Procopius, De aedificiis 2.8.11.

${ }^{51}$ See Whitby 1986, op. cit. (n. 44), 721-723; D. Roques, 'Les constructions de Justinien de Procope de Césarée: documents ou monuments?', CRAI (1988), 989-1001. On the ideology at work behind the de aedificiis see A. Cameron, Procopius (London 1985), 84-112. For the important observations made by B. Isaac on the character of Procopius' works see below.
} 
of confrontation between the two superpowers and consequently the Roman authorities decided that there was a need to further strengthen the defences of Zenobia.

The second point I intend to underline is that actually Zenobia was not built as a city located in the middle of a completely deserted area. In fact, Procopius says that Diocletian had built three phrouria in mud bricks in the desert area between Sura and the Khabour. He clarifies that one of them, Mambri, fallen into decay over time, was rebuilt by Justinian. ${ }^{52}$ Scholars have noted the existence of at least six sites of some importance along the right flank of the Euphrates between Sura and the confluence of the Khabur, all of them probably inhabited in late antiquity. Four of them, Siffin, Nouhaila, Djazla, Tell Ma'adan are situated along the first section of the route, between Sura and Zenobia; two, Tibni, which was usually identified with Mambri mentioned by Procopius, and Tabus, lay beween Zenobia and the Khabur. The research conducted on the site has revealed that Djazla was a Seleucid colony, founded in the second or in the first century вс. Its walls underwent important works of restoration in late antiquity, perhaps in Diocletian's time. It is also probable that the other three sites placed along the first stretch of the route have the same chronological sequence as Djazla, but in the absence of any excavations no firm conclusions can be drawn..$^{53}$

Recent studies have now suggested that Tibni cannot be identified with Mambri. Unfortunately, the ancient settlement lies under a Muslim cemetery and consequently it will not be investigated. On the other hand, archaeological research has been conducted at Tabus, located $28 \mathrm{~km}$. from Zenobia in the direction of the confluence with the Khabur. The site has a dimension of $300 \mathrm{~m} . \times 80 \mathrm{~m} . \times 100 \mathrm{~m}$. It displays late antique occupation, most probably stretching from Diocletian to the sixth century. ${ }^{54}$ The dimensions and the features of its circuit appear to establish that Tabus was a civilian settlement. ${ }^{55}$

52 Procopius, De aedificiis 2.8.5-7.

53 J. Napoli, 'Les remparts de la forteresse de Djazla sur le moyen-Euphrate', Syria 77 (2000), 117-136. The five miles distance given by Procopius, De aedificiis 2.8.7-8 between Mambri and Zenobia fits with Tibni's location.

${ }^{54}$ J.L. Montero Fenollos-F. Caramelo-I. Marquez-J. Vidal, 'O projecto arqueologico "Medio Eufrates Sirio": resultados provisorios de primiera campana', Revista Portoguesa de Arqueologia 9 (2006), 116 (Tibni); M. Lönnqvist, 'Archaeological survey of Jebel Bishri', Kaskal 3 (2006), 203-240; M. Lönnqvist et al., 'Archaeological surveys of Jebel Bishri. The preliminary report of the Finnish mission to Syria 2005-2006', Kaskal 6 (2009), 1-42.

${ }^{55}$ On the features of the city wall, which displays a similarity with the ones of Re- 
As we have seen, in the bella Procopius seems to describe the area between Sura and the confluence with the Khabur as quite marginal, deserted of men and without any settlements. On the other hand, a passage in the de aedificiis mentions the existence of three forts there. As far as is known, then, Tabus was the last Roman settlement downstream the river. Moreover, a detailed investigation has revealed no significant late-antique presence along the right bank of the Euphrates from Deir ez-Zor to Abu Kamal. ${ }^{56}$ That was the area that Procopius and the ps. Zacharias describe as bare and unproductive. They were thus right in affirming that the Persian attack in the year 531 was led through a Roman land that was deserted. The first settlement the Persians could have met, Tabus, was almost $100 \mathrm{~km}$. from the confluence of the Euphrates with the Khabur.

According to the Tabula Peutingeriana, the boundary of the Roman state was established at Sura: the awkward Latin of the text transmitted to us affirms that the site was Finis exercitus syriaticae et comertium Barbaros. The city functioned as an official toll station, where the goods crossing the boundary were taxed. Nonetheless, the area downstream of Sura along the right bank of the river until the confluence with the Khabur was considered to be within the Roman sphere.

Along the left bank of the river a series of fortified settlements arose in Late Antiquity. A study of the pottery at the site reveals that Tall arRum, a fortified site with an enclosure of $160 \times 150 \mathrm{~m}$., must have been founded by the first half of the fifth century $\mathrm{AD}$ at the latest, and that it was continuously occupied until Umayyad times. It is important to note that the types of ceramic used in the fourth century are still not very well known. Consequently, it still remains probable that the settlement was founded before the fifth century, ${ }^{57}$ possibly at the time of the

\footnotetext{
safa and Zenobia see M. Gschwind-H. Hasan, 'Die spätrömische-frühislamische Zivilsiedlung Tall ar-Rum und die spätantike Besiedlung des Euphrates zwischen Zenobia und Circesium', Damaszener Mitteilungen 15 (2006), 368-370. It must be remarked that extreme caution is needed before assuming that all the sites we can detect along the right flank of the Euphrates were occupied during the same span of time. In fact, recent studies have proved that al Qreiye was a Roman fort of the Middle imperial period, built by Septimius Severus, evacuated in the mid-third of the 3rd century, never to be occupied again. See M. Gschwind-H. Hasan, Das römische Kastell Qreiye-Ayyash, Provinz Deir ez-Zor, Syrien. Ergebnisse des syrisch-deutschen Kooperationsprojektes', Zeitschrift für Orient-Archäologie 1 (2008), 316-334.

${ }^{56}$ See B. Geyer-J.Y. Monchambert, La basse vallée de l'Euphrate syrien du Néolithique à l'avènement de l'Islam (Paris 2003), 280.

57 See Gschwind-Hasan 2008, op. cit. (n. 55), 321-373.
} 
Tetrarchy or some time later. As we will see, some historical considerations support such an idea.

The features of the circuit and of the road system at Tall ar-Rum resemble the ones we have already noted for the vici of Tetrapyrgium and Cholle along the route between Sura and Oriza. Hence, we must suspect that in this case, too, the building of the site was part of a wider plan, supported by the imperial government. However, unlike at Tetrapyrgium and Cholle, in the case of the fortified settlement of Tall ar-Rum we can exclude that the site included a military fort.

Tall as-Sinn and al-Kasra, with their 20 ha., are much larger sites than Tall ar-Rum. They display strong poligonal fortifications built with clay bricks. No detailed investigations have been conducted there; nonetheless it is logical to suppose that they both, together with Tall ar-Rum and Annoukas, were part of the same late-antique system which had the aim of supporting the logistics of the army and of providing facilities to the traders. $^{58}$

As far as the last site is concerned, we must observe that it was built just opposite Zenobia, on the other side of the river. Procopius says that Justinian found the wall of the fort of Annoukas, which had been built in previous times, to be completely ruined. He then rebuilt it in a magnificent way. The fortress is located in a strategic position, upon a spur overlooking the Euphrates. Scholars have noted the close similarities between the features of its city walls and those of Zenobia. That points to the idea that they were constructed in the frame of the same plan of strengthening the frontier. Moreover, an investigation at the site reveals that Procopius was right in affirming that Annoukas, although only a phrourion, had dimensions comparable to the ones of some cities. ${ }^{59}$

Unlike the situation attested on the right bank of the Euphrates where sites such as Qreye and Tabus were already occupied in the second-third century, Tall ar-Rum, Tall as-Sinn and al Qasra were built for the first time

58 Gschwind-Hasan 2008, op. cit. (n. 55), 366; 370-372; Gschwind-Hasan, 'Tall arRum. A Late Roman to Early Islamic settlement on the river Euphrates', in K. Bartl-A. alRazzaq Moaz (eds.), Residences, Castles, Settlements (Rahden 2008), 455-471; M. Gschwind, 'Every square structure a Roman fort? Recent research in Qreiye-'Ayyash and its alleged bridgehead fort Tall ar-Rum on the Euphrates', in A. Morillo-N. HanelE. Martin (eds.), Limes XX. XX Congreso internacional de estudios sobre la frontiera romana (Madrid 2009), 1593-1604. See now the the publication of the necropolis of Tall as-Sinn by J. Montero-Fenollos, La necropolis byzantine de Tall as-Sinn (Madrid 2008).

59 Procopius, De aedificiis 2.6.12. See de' Maffei 1999, op.cit. (n. 47), 172-177. 
in Late Antiquity. ${ }^{60}$ Circesium is described by Ammianus Marcellinus as a small and not well defended place before Diocletian's time. That emperor rebuilt the defences at the frontier by deploying the Roman army in barbarian territories to reduce the chances that the Persians could attack the Roman Empire, as they had previously done. Consequently, he erected high city walls with towers at Circesium which became a munimentum tutissimum et fabre politum. ${ }^{61}$

The place is listed in the Notitia Dignitatum as the base of the legio IV Parthica. However, it is known that in the year 586 the legion was stationed at Beroea. Most probably the unit had abandoned Circesium during the fifth century. Procopius reports that Justinian shifted the seat of the dux to Circesium, adding a new unit to the local garrison. The fact that a need for a military presence was felt there, suggests that only a few soldiers lived in the city at that time. It seems logical to deduce that the weakening of the military presence at Circesium, and most probably along all the sites along the middle Euphrates, had occurred during the fifth century, in the context of a general situation of more peaceful relations with the Persians. ${ }^{62}$

The last section of the frontier I intend to discuss is the one in the area of central Jordan. Along a route in the steppe bordering the desert, some $20-25 \mathrm{~km}$. beyond the via nova Traiana, a series of military installation was built in Late Antiquity, such as at Umm al-Rasas (Kastron Mefaa), Qasr el Thuraiya, Qasr el Al, Qasr Bshir (Castra Praetorii Mobeni). Expecially important was the legionary basis of Bethorus (Lejjun) where the legio IV Martia was stationed.

The traces of the route in the section north of the wadi Mujib have been observed by scholars. Its paved stones are still visible between Umm al Rasas and Qasr el Thuraiya; moreover, beyond the last mentioned fort it is possibile to observe the descent of the route into the gorge of the wadi Souaida, a tributary of the wadi Mujib. The imperial engeneers had to

${ }^{60}$ Gschwind-Hasan 2008, op. cit. (n. 55), 321-373. In absence of any archaeological research conducted on the site it is still impossible to establish the time of Annoukas' foundation.

${ }^{61}$ Ammianus Marcellinus, Res Gestae 23.5.1-2. It must be recalled that some Arab sources affirm that Circesium had belonged to the queen al-Zabba. See A. Musil, The Middle Euphrates. A Topographical Itinerary (New York 1927), 337.

${ }^{62}$ Notitia Dignitatum or. 35.24; Theoph. Sym. 2.8.9; Procopius, De aedificiis 2.6.9. For the convincing idea that the legion had been withdrawn from Circesium during the fifth century see Whitby 1986, op. cit. (n. 44), 725. See also Greatrex 2007, op. cit. (n. 13), 92. 
overcome great difficulties in order to build such a road that descended to the bottom of the wadi and went up again. It can be argued that such a military system was conceived by Diocletian and Galerius: in fact, a group of Tetrarchic milestones, unfortunately still unpublished, has been found along the route near Umm al-Rasas. Moreover, a fragmentary Latin inscription attests to the presence of the Roman army at Umm al Rasas in 306. The site has been identified with the Mefa listed in the Notitia Dignitatum as the base of a unit of equites promoti indigenae. ${ }^{63}$ It is now clear that such a type of unit was deployed in the near eastern ducates in Tetrarchic times. ${ }^{64}$

Surveys and excavations conducted in sites as Qasr el Thuraiya, Qasr Bshir, the legionary fort of Lejjun and other minor sites south of the wadi Mujib show that they were occupied for the first time in the Tetrachic age. Detailed archaeological research has shown that a series of towers and minor military installations was built in this section of the frontier. All the structures were part of a complex system where the sites were at such a distance as to enable them to communicate one with another through optical signaling. Such a system was still active at the time of the Notitia which lists Bethorus and Mefaa among the bases occupied by Roman soldiers. However, it has been detected that by AD 500 it was no longer active. In fact, at that time Qasr el Thuraiya, Qasr Bshir and Khirbet el-Fityan, together with all the other minor sites south of the wadi Mujib, had been abandoned. ${ }^{65}$

At the legionary camp at el Lejjun some of the the barracks in the praetentura were not rebuilt after the earthquake of 363 . It must be deduced that the new accommodations were provided for a unit that was now reduced in respect to the original one. Moreover, it is probable that the vicus attached to the fort was abandoned in the same years. In fact, surveys made at three different buildings in the vicus have detected a lack of occupation after 363 . Nonetheless, the fort itself continued to be occupied until the mid-sixth century. The evidence shows a female presence in the fort during the fifth and sixth century and it is logical to assume that the families of the soldiers moved to live inside the fort.

${ }^{63}$ A. Lewin, 'Kastron Mefaa, the equites promoti indigenae and the Creation of a Late Roman Empire', Liber Annuus 51 (2001), 293-304.

${ }^{64}$ Lewin 2004, op. cit. (n. 9).

65 S.T. Parker, Romans and Saracens. A History of the Arabian Frontier (Winona Lake 1986), 74-86; S.T. Parker, 'History of the Roman frontier east of the Dead Sea', in S.T. Parker (ed.), The Roman Frontier in Central Jordan. Final Report on the limes arabicus Project 1980-1989 (Washington D.C. 2006), 565-566. 
Parker has argued that after the eartquake of AD 502 the fort was less intensively inhabited. ${ }^{66}$ The character of this late occupation is under discussion and Parker's view that it was very reduced has now been challenged ${ }^{67}$ The fort was evacuated after the earthquake of the year 551 . The settlements that had grown on the the eastern plateau and adjacent desert fringe were largely abandoned by sedentary populations in the sixth century. ${ }^{68}$

As far as Umm al-Rasas is concerned, it is important to note that the research conducted by the Franciscan fathers shows the absence of fifth-century ceramics in the investigated areas. That would lead us to assume a gap in the occupation of the site during the fifth century. Moreover, the same trend appears to emerge at the neighbouring site of Nitl, where the area of the complex of Saint Sergius has been investigated by Basema Hamarneh. ${ }^{69}$ On the other hand, it is possible that the final report of the archaeological research conducted by the Swiss team lead by Jacques Bujard on other areas of Umm al-Rasas will modify such negative conclusions.

A new phase in the life of this section of the frontier in central Jordan emerged in the following century. The area within the fort of Kastron Mefaa became a village with four churches; the settlement expanded to the area outside the fort as well, where another ten churches arose. The churches were adorned with beautiful mosaics; many of them were discovered and studied by father Michele Piccirillo whose death is now deeply regretted. ${ }^{70}$

Another fascinating mosaic was found in the church dedicated to Saint Sergius in the nearby village of Nitl, $12 \mathrm{~km}$. north east of Mefaa. A group of inscriptions reveal that the Ghassanids-or rather as scholars have pointed out, the Jafnids-who were the chief arab allies of Rome at that time, had a strong impact on the village life. One of their leaders

\footnotetext{
${ }^{66}$ Parker 2006, op. cit. (n. 65), 561.

${ }^{67}$ C. Whately, 'El-Lejjun: Logistics and localization on Rome's eastern frontier in the sixth century', forthcoming.

68 Parker 2006, op. cit. (n. 65), 567-569.

${ }^{69}$ E. Alliata, 'Ceramica romana, bizantina, araba', in M. Piccirillo-E. Alliata (eds.), Umm al-Rasas Mayfa'ah. I. Gli scavi del complesso di S. Stefano (Jerusalem 1994), 279282; B. Hamarneh, 'Relazione dello scavo del complesso ecclesiale di Nitl, stratigrafia e ceramica', Liber annuus 56 (2006), 399-458.

${ }^{70}$ For a bibliography of Piccirillo's publications on Umm ar-Rasas, see B. Hamarneh, Topografia cristiana ed insediamenti rurali nel territorio dell'odierna Giordania nelle epoche bizantina ed islamica V-IX sec. (Città del Vaticano 2003), 326-330.
} 
was buried in the church itself. ${ }^{71}$ The great development that occurred at Mefaa and at Nitl must, therefore, have been heavily influenced by the presence of the Ghassanids, who revitalized the area, offering an effective protection to the population. Probably some groups of the same confederation settled and inhabited the two villages.

It is time now to offer some evaluation of the dynamics of the development of the four sections of the frontier we have investigated. First of all, they display different features and tipology of development. However, they have in common that they were reorganised, and in some cases organised for the first time, according to a plan launched by Diocletian. Most probably, until the beginning of the fourth century no coherent military system existed between Palmyra and Damascus beyond the Jebel Rawaq. However, the Tetrarchic organization of the route with its series of forts did not survive for a long time. In fact it seems that it was during the fifth century that the structures along "la route des khans" were abandoned.

The research conducted by Thomas Parker with his team prove that in central Jordan, south of the wadi Mujib, Diocletian and Galerius installed the army in marginal places not previously occupied by Roman soldiers. In particular, the fort of Lejjun was built on a virgin site. On the other hand, we cannot be sure that Umm al-Rasas had not been settled before the Tetrarchs installed a garrison of equites promoti indigenae there. In fact, ceramics of earlier times have been found at the site and such material still needs to be studied. ${ }^{72}$

The route in central Jordan south of the wadi Mujib was quite marginal. Most probably it was built for the movement of troops and travellers as an alternative route to the via nova Traiana, which in the wadi Mujib section used to be flooded after seasonal rains. However, such a system with a route beyond the via nova Traiana and a series of military installations connecting the area north of the wadi Mujib with the territory to the south of it came to an end during the fifth century. South of the wadi some military occupation, clearly reduced, continued only at the fort of Lejjun.

As we have seen, however, it is possible that new publications will reveal the presence of fifth-century ceramics at Umm al-Rasas. The same remains true for the results of the next excavations at Nitl. If so, the idea

71 See Lewin 2007 , op. cit. (n. 3), 474-476; 480 with the relevant bibliography.

72 Information provided by D. Genequand. 
of a gap in the occupation of the site could be rejected and the one of a continuous presence of soldiers with their families advanced. These people could have transformed the look of the fort, constructing houses, roads and churches and extending the settled area beyond the walls. There are indeed some cases where it is possible to argue that at least a few limitanean soldiers used to live in a village, together with their families and the rest of the civilian population. For example, some inscriptions reveal that at Shivta in the Negev the soldiers and the officers of the army lived in the village in the sixth century; however, no fort is discernible at the site. Moreover, at Nessana and Avdat fortified enclosures were built on the acropolis. In the final stage there were twenty-seven small rooms at the fortress of Nessana and only two at the one at Avdat. ${ }^{73}$ Probably the soldiers did not live in the rooms, which were used for storing weapons or for keeping documents.

Nonetheless, in light of all the other evidence we have about the situation in central Jordan, we must suppose that at Umm al-Rasas as well the trend was towards a shrinking of the military presence. Moreover, although the place was called Kastron Mefaa in sixth-century inscriptions, it is obvious that such a fact cannot prove that a military unit was still there at that time. Also, assuming that the ceramic material will indeed reveal continuity in the occupation of Umm al-Rasas through the fifth century, such evidence per se cannot represent proof that the development at Umm al Rasas and Nitl was due to the military presence. After all, the few soldiers with their families who lived in Lejjun in the fifth century and perhaps in the first half of the sixth, were not capable of expanding the inhabited area of the site beyond the walls of the fort.

${ }^{73}$ See Lewin 2007, op. cit. (n. 3), 469-480. That does not imply that in the Near East no new fort was built at a late date for housing soldiers. See J. Magness, 'Redating the forts at Ein Boqeq, Upper Zohar, and other sites in se Judaea, and the implications for the nature of the Limes Palaestinae', in J. Humphrey (ed.), The Roman and Byzantine Near East. Volume 2. Some Recent Archaeological Research (Portsmouth 1999), 189-206 where it is argued that the archaeological evidence shows that the fortlets at Ein Boqeq and Upper Zohar were built in the mid-sixth century. At Sura, a new fort whose ruins are still visible was built by Justinian after the Persian attack had destroyed the city and the old fort. See Konrad 1999, op. cit. (n. 15), 398-400; Konrad 2001, op. cit. (n. 6), 6-7; 12. On the other hand, no sixth-century fort is discernible among the ruins of Resafa. The old one built by the Tetrarchs had been abandoned already several decades before a new church was built in its area. M. Konrad (personal communication) observing that the towers at Resafa are quite big suggests to keep in mind the possibility that the soldiers were lodged in them. For changes in the character of the limitanean army, due to the fact that soldiers were allowed to own lands see C. Zuckerman, 'Larmée', in C. Morrisson (ed.), Le monde byzantin I. L'Empire romain d'Orient (330-641) (Paris 2004), 154-163. 
In fact, they abandoned the vicus. The most probable reason for the important development which occurred at Umm al-Rasas and Nitl must remain the impulse given to it by an external force, the Jafnids.

In the section between Sura and the Khabur, Diocletian built only three forts. On the left bank of the Euphrates he enlarged the small site of Circesium, connecting it to Callinicum by a military route. Some fortified villages were built along it; presumably the imperial authorities were involved in supporting the enterprise. Most probably a weakening of the military presence along the route occurred during the fifth century. In fact, as we have seen, there are some indications that the legion installed at Circesium by Diocletian was transferred elsewhere in the fifth century. In Justinian's time the situation changed again: relations with Persia deteriorated and the area became the focus of renewed military activity. The walls of Circesium were strengthened and the defences of the city were reinforced with the transfer of soldiers. On the right bank of the river Zenobia now emerged as a solid stronghold, according to the new imperial strategic plans.

We can be sure that the section of the frontier between Sura and Palmyra did not experience a gap in occupation in the fifth century. A very detailed and scholarly study, conducted by Michaela Konrad at the fort of Tetrapyrgium, has revealed the presence of ceramic of the late fifth and the beginning of the sixth century. ${ }^{74}$ If that fort, as it is logical to argue, was part of a military system built along the frontier route, the other installations were not abandoned in the fifth century. An impulse for the development of the area was given by the presence of a famous Christian shrine at Resafa. Moreover, as we have seen, all the sites were located at good water points, a fact that enabled them to develop agriculture.

To conclude: two main issues have been discussed by scholars in recent years. First, they have advanced the idea that a weakenining of the military presece in the ducates of the Near East occurred in the fifth century. The peaceful relations with the Persians prompted a lesser investment in the upkeeping of the Near-Eastern frontiers, the Arab allies of the Persians remained quiet for many years, and the ducates allowed a reduced presence of soldiers. It was such a reduced presence of the limitanean army that made the success of Amorkesos' ambitious plans at the time

${ }^{74}$ Konrad 2001, op. cit. (n. 6), 171; 74-75. 
of the emperor Leo easier. This Arab chief succeeded in occupying the island of Jotabe, threatening the borders of Palaestina III and eventually became officially acknowledged as phylarch by the emperor. It is probable that before that time the limitanean army had been further weakened by its participation in the African campaign against the Vandals undertaken by Leo. The African expedition was a failure and most of the army perished in it. ${ }^{75}$

On the other hand, we cannot be sure that the situation along the near-eastern frontier from the Euphrates to the Red Sea was always peaceful throughout the fifth century. In fact, some sources reveal that conflicts with Arab tribes at the borders of the aforementioned ducates occurred also in years when there was no war between the Persians and the Romans. ${ }^{76}$ According to the evidence examined in this article, the idea of a weakening military presence in the fifth century must be maintained. The section of the frontier beyond the Jebel Rawaq was dismantled and the same happened to the system in Central Jordan. If some forts remained occupied, as was the case at Lejjun, they were the exception.

A reduction of the military presence in the two other sections of the frontier we have examined can be surmised by the fact that at Justinian's time the need was felt to reinforce the garrisons at both Circesium and Palmyra. However, that does not imply that during the fifth century all the soldiers had been withdrawn from the sites along those sections of the frontier. Moreover, it must be observed that there is some documentation from other sections of the Near East showing that military forces had been withdrawn from their bases. The small fort of Yotvatah, built at the time of the first Tetrarchy, was abandoned in the second part of the fourth century. The fort of Udruh, built around the year 303 as a base for the legio VI Ferrata, is not mentioned in the Notita Dignitatum where the legion itself is also absent. In the northern part of the ducate of Arabia the fort at $\mathrm{Sa}^{\prime}$ aneh, built around 300 , does not show traces of occupation in the fifth century. ${ }^{77}$

\footnotetext{
${ }^{75}$ See G. Fisher, 'A new perspective on Rome's desert frontier', Bulletin of the American Schools of Oriental Research 336 (2004), 49-60 who exploring the results of recent archaeological excavations and the witness of literary sources shows that a weakening of the Tetrarchic military apparatus already begun in the second half of the fourth century; I. Shahid, Byzantium and the Arabs in the Fifth Century (Washington 1989), 59-113.

76 A.S. Lewin, 'Amr ibn 'Adi, Mavia, the Phylarchs and the Late Roman army. Peace and war in the Near East', in Lewin-Pellegrini 2007, op. cit. (n. 5), 254.

77 U. Avner-G. Davies-J. Magness, 'The Roman fort at Yotvatah: interim report
} 
We can assume that the weakening of the limitanean army led to a more intense use by the Roman government of the Arab allies as brokers between the world of the agriculturalist and the one of the pastoralists living astride the frontiers. The Arab allies could have effectively worked at inspecting the movements of the pastoralists, monitoring their access to the farmed lands at the time of the seasonal migrations. In particular, it is well attested that in the sixth century the Jafnids had the task of supporting the limitanean army against the attacks brought by hostile Arab tribes, expecially the Nasrid allies of the Persians.

The second issue that deserves attention is the problem of a supposed disbandment of the limitanei in Justinian's reign. A famous statement by Procopius has long puzzled scholars. The writer says that the emperor, after having left the limitanei unpaid for four to five years, requested some sums of money from them. Finally they lost the title of soldiers. ${ }^{78}$ It is not only that the value of the story has been severely challenged. The character of Procopius' grand general statements in the de aedificiis and in the Anekdota has itself undergone radical criticism: Procopius says explicitly that under Justinian churches anywhere in the empire were built or restored with imperial funds only. The statement is definitely not true, and this is of interest for our judgement of the author: he must have known it was untrue and that his readers were aware that it was untrue, like his passing remarks that Justinian 'abolished' the limitanei. He does, however, mention by name numerous churches which Justinian built or restored. ${ }^{79}$ Yet, the dearth of coins dated to the years after 540 in some forts of Palaestina has been seen by John Casey as a proof of the veracity of Procopius' statement, at least as far as that province was concerned. Other scholars have advanced the idea that his observation could be enlarged to other areas of the Near East. ${ }^{80}$

\footnotetext{
(2003)', Journal of Roman Archaelogy 17 (2004), 405-412 (Yotvatah); Kennedy-Falahat 2008, op. cit. (n. 5) (Udruh); M. Lenoir, 'Sa'aneh ou le désert des tartares: un camp oublié du limes arabicus', Syria 80 (2003), 145-157 (Sa'aneh). It must be recalled that the fort at Avdat, built at the time of of the Tetrarchy, was abandoned few decades later, probably at the time of Constantine. See T. Erickson-Gini, 'Nabataean or Roman? Reconsidering the date of the camp at Avdat in light of recent excavations', in Ph. Freeman et al. (eds.), Limes XVIII. Proceedings of the XVIIIth International Congress of Roman Studies (Oxford 2002), 113-130. It remains probable that the unit stationed at Avdat was later transferred to a site closer to the edge of the empire.

78 Procopius, Anecdota 24.12-14.

79 Isaac 1990, op. cit. (n. 41), 368.

$80 \mathrm{~J}$. Casey, 'Justinian, the limitanei, and Arab-Byzantine relations in the 6th century', Journal of Roman Archaeology 9 (1996), 214-222. See also Konrad 2001, op. cit. (n. 6),
} 
However, the continuity of the presence of Roman military units in Palaestina at Justinian's time and later is solidly attested by inscriptions and papyri. ${ }^{81}$ Moreover, new forts were built at Ein Boqeq and Upper Zohar in the mid sixth century. ${ }^{82}$ In the ducate of Arabia an inscription attests that the fort of Hallabat was restored in $529 .{ }^{83}$ At the end of the twenties of the sixth century Justinian was reinforcing the military apparatus along the borders of the near eastern ducates. We have seen that he transferred some units to Palmyra in 527. Most probably, it was at the same time or very few years later that he deployed some soldiers in Resafa and Circesium and began to rebuild Zenobia. When Resafa was besieged by Chosroes in 542, it had still two hundred soldiers in it. Moreover, the building of a new fort at Sura in the forties must prove the presence of a unit there. More than thirty years ago, Wolf Liebeschuetz argued that, although the strata diocletiana between Palmyra and Damascus had been abandoned in the fifth century, there were still some military forces in Syria in the sixth century. ${ }^{84}$ We have seen that new documents and a fresh examination of the sources reinforce his view.

Another important issue deserves attention: as we have seen, the return of the conflict with the Persians by Anastasius' time led the emperors to strengthen the military apparatus at the near-eastern frontiers. Two

who noting the absence of Justinianic issues post dating at Tetrapyrgium argues that the Roman garrison had been disbanded by that time. The presence of ceramic material is explained by the fact that Arab allies, who presumably did not receive a cash payment, replaced the Roman soldiers in the fort. For difficulties in the payment of the army, already in the thirties, see Greatrex 1998, Rome and Persia, op. cit. (n. 13), 219-220.

${ }^{81}$ See B. Isaac, 'The army in the Late Roman east: the Persian Wars and the defence of the Byzantine provinces', in A. Cameron-L. Conrad-G. King (eds.), The Byzantine and Early Islamic Near East III. States, Resources and Armies (Princeton 1995), 125-155; A. Cameron-L. Conrad-G. King (eds.), The Near East under Roman Rule. Selected Papers (Leiden 1998), 437-469. For some corrections see L. Di Segni, 'The Beer Sheba Tax Edict reconsidered', Scripta classica israelica 23 (2004), 149-150, n. 69. For an up-todate discussion of the sources, see Z.T. Fiema, 'The military presence in the countryside of Petra in the 6th century', in Ph. Freeman et al. (eds.), Limes XVIII. Proceedings of the XVIIIth International Congress of Roman Studies (Oxford 2002), 131-136; Z.T. Fiema, 'The Byzantine military in the Petra papyry-a summary', in Lewin-Pellegrini 2007, op. cit., (n. 5), 313-319; G. Greatrex, 'Les Jafnides et la défense de l'empire au VIe s.', in D. Genequand-Ch. Robin (eds.), Regards croisés de l'histoire et de l'archéologie sur la dynastie Jafnide, forthcoming.

${ }_{82}$ Magness 1999, op. cit. (n. 73).

83 D.L. Kennedy, Archaeological Explorations on the Roman Frontier in North-East Jordan (Oxford 1982), 40.

${ }^{84}$ W. Liebeschuetz, 'The defences of Syria in the sixth century', in D. Haupt-H.G. Horn (eds.), Studien zu den Militärgrenzen Roms II (Köln 1977), 487-499. 
new large fortresses were built, Dara and Zenobia. The Roman government, however, combined the program of reinforcement of the military defences with an important plan of urbanisation of the cities at the frontiers. ${ }^{85}$ So the deployment of military forces at the borders of the empire had the effect of creating new cities and of shifting the main characters of the Roman urban culture to the most peripheral areas of the Near East. Cities, such as Palmyra, where stagnation had occurred during the time of the long peace with the Persians, were now furnished with new civic monuments. Still, the measure of the financial involvement of the imperial government in the realisation of new urban monuments is under discussion. Some inscriptions confirm that the emperors were credited with the realisation of important works, but in other cases the initiative was a local one. ${ }^{86}$

Finally, it must be stressed that all along the frontier from Sura to Aila on the Red Sea the external threat that the Romans had to cope with was represented by the Arab tribes. Their activities had to be controlled, negotiated, and eventually opposed when hostile attacks materialised. In time the Arab allies of Rome became involved in supporting the Roman army in such important tasks. ${ }^{87}$ It is important to observe that the Persians were never active along this section of the frontier. According to Procopius, when Justinian reinforced the defences at Palmyra at Resafa he had in mind the Saracen threat. ${ }^{88}$ It was only as revenge against the bishop of Resafa, Candidus, that Chosroes led his army against Resafa in $542 .{ }^{89}$

${ }^{85}$ S. Janniard, 'Armée et "acculturation" dans l'Orient romain tardif: l'exemple des confins syro-mésopotamiens (V-VI s. apr. J.C.)', Mélanges de l'Ecole Francaise de Rome 118 (2006), 133-149.

${ }^{86}$ D. Feissel, 'Les édifices de Justinien au témoignage de Procope et de l'épigraphie', Antiquités tardives 8 (2000), 81-104. Two inscriptions show that the local bishopric of Resafa organised and financed two important buildings there. See Ulbert 2000, op. cit. (n. 25), 142-145. See also Isaac 1990, op. cit. (n. 41), 365-371; E. Zanini, 'The urban ideal and urban planning in Byzantine new cities of the sixth century AD', in L. LavanK. Bowden (eds.), Theory and Practice in Late Antique Archaeology (Leiden 2003), 196223. For the character of the sixth-century urbanisation see now the splendid book by H.G. Saradi, The Byzantine City in the Sixth Century. Literary Images and Historical Reality (Athens 2006).

${ }^{87}$ Lewin 2007, op. cit. (n. 71); Lewin 2007, op. cit. (n. 76), 155-173; W. Liebeschuetz, 'Nomads, Phylarchs, and settlement in Syria and Palaestine', in Lewin-Pellegrini 2006, op. cit. (n. 4), 131-145.

88 Procopius, De aedificiis 2.9.3-4; 2.11.10.

89 Procopius, De bellis 2.5.29-32; 20.1-16. 
This is very different from the situation of the third century, when the invasion led by Shapur I used the route along the Euphrates as a Persian axis of penetration. Diocletian strongly reinforced Circesium and built other military installations there in order to avoid new attacks conducted along the flanks of the river. Nonetheless, until the sixth century, that part of the frontier did not become a focus of military confrontation with Persia. Only the Arab tribes hostile to Rome used to roam there and eventually the Jafnid Al-Mundhir revealed its strategic importance to the Persian king. ${ }^{90}$

Florence, January 2011

90 Procopius, De bellis 1.17.30-39; 1.18.2. 